\title{
Determinations and residual characteristics of triclosan in household food detergents of Taiwan
}

\author{
Shih-Wei Tsai ${ }^{\mathrm{a}, *}$, Mei-Wen Shih ${ }^{\mathrm{b}}$, Yi-Ping Pan ${ }^{\mathrm{a}}$ \\ a Institute of Environmental Health, College of Public Health, National Taiwan University, No. 17, Xuzhou Road, Taipei 100, Taiwan \\ ${ }^{\mathrm{b}}$ Department of Occupational Safety and Health, China Medical University, No. 91, Hsueh-Shih Road, Taichung 404, Taiwan
}

\section{A R T I C L E I N F O}

\section{Article history:}

Received 22 January 2008

Received in revised form 22 April 2008

Accepted 5 May 2008

Available online 16 June 2008

\section{Keywords:}

Triclosan

Food detergents

Exposure

Taguchi method

HPLC

\begin{abstract}
A B S T R A C T
Triclosan (2,4,4'-trichloro-2'-hydroxydiphenyl ether) is a widely used antibacterial agent. However, it was concerned recently that triclosan might act as an antibiotic and will cause resistant bacterial strains. Furthermore, possible formation of toxic chloroform was also reported when the triclosan contained in household dishwashing soaps reacted with the chlorinated water. To assess the associate risks from possible exposures, concentrations of triclosan in household food detergents of Taiwan were determined in this study. High performance liquid chromatography (HPLC) with UV detector at $280 \mathrm{~nm}$ was used to analyze the triclosan in samples. Factors that might affect the residual characteristics of triclosan from detergents on dishware and fruits, including the concentrations of detergents used, the temperature and immersion time for water before the cleaning processes, the temperatures of water used for the cleaning processes, and the materials of dishware made of, were evaluated under the orthogonal experiment design by the Taguchi method. By the analysis of variance, the orders of importance of different parameters were determined. The concentrations of triclosan detected in household food detergents were found to be $1.7 \times 10^{-2}-5.6 \times 10^{-1}$ (triclosan/detergent, $\mathrm{mg} \mathrm{g}^{-1}$ ). For residual characteristics, the concentration of detergents used as well as the materials of dishware were found to be the significant factors that will affect the triclosan left on the dishware. On the other hand, the concentration of triclosan in the detergents was found to be the only factor that will affect the triclosan left on fruits. The maximum dose of triclosan exposures from the use of household food detergents in Taiwan was also estimated in the study.
\end{abstract}

(c) 2008 Elsevier Ltd. All rights reserved.

\section{Introduction}

Food detergents are widely used for dish washing and fruit cleaning in modern daily life. The major components of detergents are surfactants which consist of a polar head group and a nonpolar hydrocarbon tail (Ying, 2006), and the world production of synthetic surfactants amounts to 7.2 million tons annually (Di Corcia, 1998). There are three types of surfactants, including anionic, nonionic and cationic. Among the commercial surfactants, linear alkylbenzene sulphonates (LAS), aklyl ethoxy sulphates (AES), alkyl sulphates (AS), alkylphenol ethoxylates (APE), akyl ethoxylates (AE), and quaternary ammonium compounds (QAC) are commonly used (Ying, 2006).

Besides having surfactants as the main components, antibacterial agents might also be contained in many synthetic detergents. For example, it was investigated that $40 \%$ of the household food detergents were labeled to have antibacterial agents in Taiwan (Tsai, 2005). Not only been found in food detergents, the entry of

\footnotetext{
* Corresponding author. Tel.: +886 23322 8097; fax: +88622351 6289 .

E-mail address: shihweitsai@ntu.edu.tw (S.-W. Tsai).
}

products containing antibacterial agents into households has escalated from a few dozen products in the mid-1990s to more than 700 today even though an added health benefit has not been demonstrated (Levy, 2001).

Among different kinds of antibacterial agents, triclosan $\left(2,4,4^{\prime}-\right.$ trichloro-2'-hydroxydiphenyl ether) is very commonly used in a number of products as diverse as toothpaste, detergents, household sponges, plastic cutting boards, socks and underwear (Adolfsson-Erici et al., 2002). Because of its high antimicrobial effectiveness and its easy processibility in solutions and solids, the popularity of triclosan has continuously increased over the last 30 years (Singer et al., 2002). For example, around 350 tons of triclosan are presently used as antimicrobial substance in many products in Europe, such as pharmaceutical and personal care products (Ciba Specialty Chemical, 1998).

The formula of triclosan is $\mathrm{C}_{12} \mathrm{H}_{7} \mathrm{Cl}_{3} \mathrm{O}_{2}$ with molecular weight equal $289.5 \mathrm{~g} \mathrm{~mol}^{-1}$ (Halden and Paull, 2005). The melting point and $\log K_{\text {ow }}$ of triclosan are $180^{\circ} \mathrm{C}$ and 4.8 , respectively (Halden and Paull, 2005). Besides, it is believed that triclosan is biodegradable and could be removed from natural waters (Lindström et al., 2002). 
Even triclosan has an excellent overall safety and efficacy profile demonstrated by over 30 years of safe use, it was concerned recently that triclosan might act as an antibiotic and will cause resistant bacterial strains (McMurry et al., 1998). On the other hand, it has been reported that triclosan used in household dishwashing soaps might react with chlorinated water to produce significant quantities of chloroform (Rule et al., 2005; Fiss et al., 2007). Studies have shown that triclosan and free chlorine readily react to form byproducts that include chlorinated phenoxy-phenols, chlorinated phenols, and trihalomethanes (Kanetoshi et al., 1987; Canosa et al., 2005; Rule et al., 2005). Besides, it was reported that various chlorinated dioxins might be formed when triclosan was exposed under sunlight (Kanetoshi et al., 1988). Furthermore, triclosan may also undergo cyclization to form toxic 2,8-dichlorodibenzo-pdioxin $\left(2,8-\mathrm{Cl}_{2} \mathrm{DD}\right)$ in aqueous solution under UV irradiation (Latch et al., 2003).

The same as its popularity around the world, $43 \%$ of the antibacterial agents added in food detergents of Taiwan were labeled to contain triclosan (Tsai, 2005). However, the distributions of concentrations are unknown and there is no regulation currently available to limit the use of triclosan in food detergents of Taiwan.

The possible health impact of the exposures to triclosan from using food detergents has not been addressed in the existing literature. It is also unclear if different conditions of detergents using processes will affect the levels of triclosan left on the dishware or fruits. Therefore the concentrations of triclosan in household food detergents of Taiwan were investigated in this research. Besides, residual characteristics under different conditions of detergents using were also determined. The Taguchi method and the orthogonal design of experiment were performed to estimate the effects of different parameters.

\section{Experimental}

\subsection{Reagents and chemicals}

Unless noted otherwise all high purity chemicals and solvents were purchased from Aldrich (Milwaukee, WI, USA), Tedia (Fairfield, OH, USA) and Merck (Darmstadt, Germany), and were used without further purification. Deionized water was further purified with a Mini-Q Plus water purification device (Millipore, Bedford, MA).

\subsection{Calibration graphs}

Stock solution of triclosan (600 $\mathrm{mg} \mathrm{l}^{-1}$ ) was prepared in methanol. This solution was then used to prepare standard solutions of triclosan (1-180 $\mathrm{mg} \mathrm{l}^{-1}$ ). Each standard solution was injected in triplicate into the chromatograph. The peak areas were plotted against the corresponding triclosan concentrations to obtain the calibration graph.

To determine the precision and accuracy of the analytical method, spiked triclosan samples ( $30 \mathrm{mg} \mathrm{l}^{-1}$ ) of detergents were analyzed seven times. The relative standard deviation (RSD) and accuracy were then calculated. Another spiked samples $\left(1 \mathrm{mg} \mathrm{l}^{-1}\right)$ were also analyzed seven times to determine the method detection limits (MDLs) based on the following procedures (US CFR 40, Part 136, Appendix B):

$\left.\mathrm{MDL}=S t_{(n-1,1-\text { alpha }}=0.99\right)$

where MDL $=$ the method detection limit; $\left.t_{(n-1,1-\text { alpha }}=0.99\right)=$ Student's $t$ value for the 99\% confidence level with $n-1$ degrees of freedom; $n$ =number of replicates; $S=$ standard deviation of replicate analyses for $n=7$ and alpha $=0.01, \mathrm{t}_{(n-1,1-\text { alpha }=0.99)}=$ 3.143.

\subsection{Samples collection and preparation}

The food detergent samples were purchased from major supermarkets and local stores from northern to southern Taiwan with various compositions and were representative of the typical food detergent samples in Taiwan. However, dishwasher detergent was not included in this study because it was not commonly used nationwide.

Among the food detergent samples purchased, 30 of them were found to be labeled having antibacterial agents. These detergent samples were further diluted to $6.7 \mathrm{~g} \mathrm{l}^{-1}$ with methanol (CNS standards, 2000). Afterwards, the determinations of triclosan for the

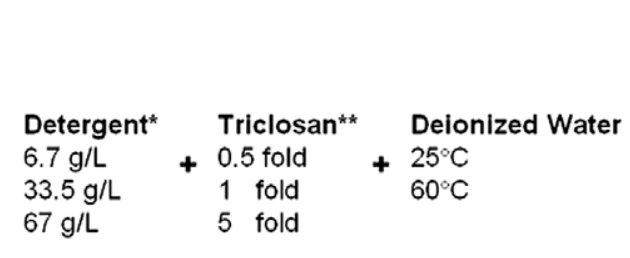

Step 1

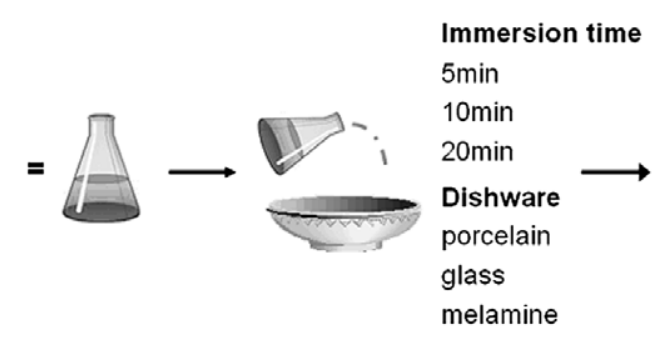

Step 2

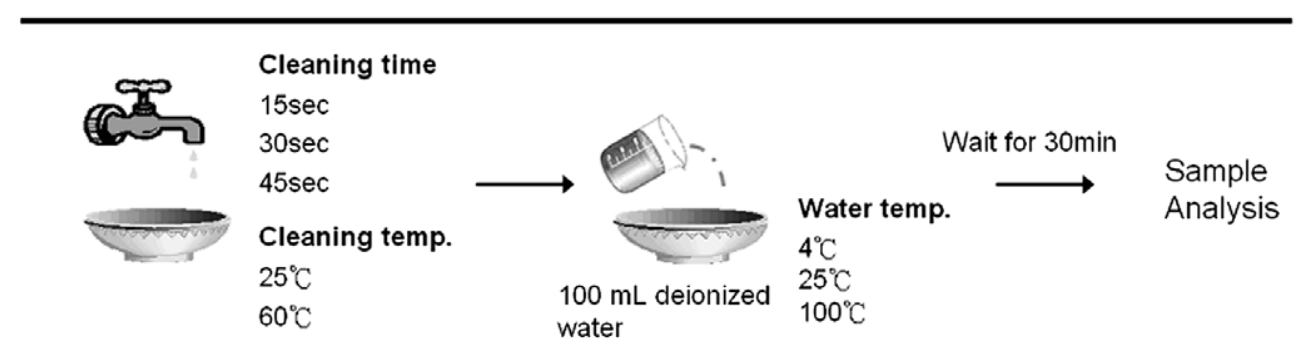

Step 3

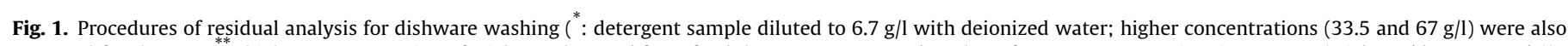

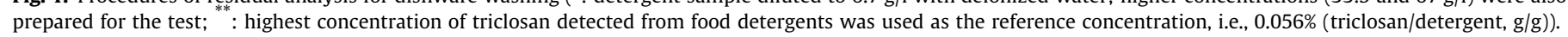


detergent samples, which were labeled having antibacterial agents, were performed by the high performance liquid chromatography (HPLC).

After the measurements, food detergents with no triclosan detected were selected as the media for further determinations of residual characteristics. As shown in Fig. 1, typical process for dishware cleaning with detergent in Taiwan was simulated. In step 1, known concentrations of detergent and triclosan were prepared with either $25^{\circ} \mathrm{C}$ or $60^{\circ} \mathrm{C}$ of deionized water. For step 2, the solution prepared in step 1 was poured into dishware and immersed for 5-20 min. The solution was then poured out of the dishware and $25^{\circ} \mathrm{C}$ or $60^{\circ} \mathrm{C}$ of water was used to clean the dishware for $15-45 \mathrm{~s}$ (step 3). After cleaning, $100 \mathrm{ml}$ of $4-100{ }^{\circ} \mathrm{C}$ of deionized water was poured into the dishware again to simulate the using conditions of dishware after cleaning (step 4), and the sample was taken for analysis after $30 \mathrm{~min}$ (step 5). In brief, an orthogonal array experiment (Taguchi experiment) (Hicks, 1999) with variation of eight experimental parameters mentioned above was con- structed. Table 1 showed the following $\mathrm{L}_{18}\left(3^{6} \times 2^{2}\right)$ orthogonal array comprised of eight columns and 18 rows.

Another orthogonal array experiment with variation of four experimental parameters was also constructed for the evaluation of residuals on three different kinds of fruits, including apple, tomato and grape (Table 2). To determine the residual characteristics, known concentrations of detergent and triclosan were prepared with $25^{\circ} \mathrm{C}$ of deionized water. As shown in Fig. 2, the solution prepared was then poured into beaker with fruits inside and immersed for 5-20 min. Afterwards, the fruit samples were chopped into small pieces and homogenized by a food blender. Around $10 \pm 0.01 \mathrm{~g}$ of fruit sample was then weighed into a $40 \mathrm{ml}$ screw-cap centrifuge tube followed by adding $10 \mathrm{ml}$ of hexane with immediately hand-shaking for $2 \mathrm{~min}$. The hexane layer was removed and kept in a vial after further centrifuge at $3000 \mathrm{rpm}$ for $10 \mathrm{~min}$. The extractions with hexane were repeated three times and all the collected hexane were evaporated to dryness in fume hood (Sanches-Silva et al., 2005). Afterwards, the solid residue

Table 1

$\mathrm{L}_{18}\left(3^{6} \times 2^{2}\right)$ orthogonal array for residual characteristics determinations on dishware

\begin{tabular}{|c|c|c|c|c|c|c|c|c|c|c|}
\hline Trial & $\begin{array}{l}\text { Immersion } \\
\text { temp. }\left({ }^{\circ} \mathrm{C}\right)\end{array}$ & $\begin{array}{l}\text { Cleaning } \\
\text { temp. } \\
\left({ }^{\circ} \mathrm{C}\right)\end{array}$ & $\begin{array}{l}\text { Dishware } \\
\text { materials }\end{array}$ & $\begin{array}{l}\text { Detergent } \\
\text { conc. }^{\mathrm{a}} \\
\left(\mathrm{g} \mathrm{l}^{-1}\right)\end{array}$ & $\begin{array}{l}\text { Triclosan } \\
\text { conc. }^{\text {b }}\end{array}$ & $\begin{array}{l}\text { Immersion } \\
\text { time (min) }\end{array}$ & $\begin{array}{l}\text { Cleaning } \\
\text { time } \\
(\mathrm{min})\end{array}$ & $\begin{array}{l}\text { Sampling } \\
\text { temp. } \\
\left({ }^{\circ} \mathrm{C}\right)\end{array}$ & $\begin{array}{l}\text { Note } 1 \text { : Triclosan in } \\
\text { deionized water before the } \\
\text { test }\left(\mathrm{g} \mathrm{l}^{-1}\right)\end{array}$ & $\begin{array}{l}\text { Note 2: Triclosan left on } \\
\text { dishware ( } \mathrm{g} \text { triclosan/l } \\
\text { deionized water) }\end{array}$ \\
\hline 1 & 25 & 60 & Porcelain & 6.7 & 5 -fold & 10 & 15 & 80 & $1.88 \times 0^{-2}$ & $1.23 \times 10^{-3}$ \\
\hline 2 & 60 & 60 & Glass & 33.5 & 1-fold & 5 & 15 & 80 & $1.88 \times 10^{-2}$ & $6.08 \times 10^{-4}$ \\
\hline 3 & 25 & 25 & Porcelain & 67 & 0.5 -fold & 5 & 15 & 4 & $1.88 \times 10^{-2}$ & n.d. \\
\hline 4 & 25 & 25 & Glass & 33.5 & 5-fold & 10 & 30 & 25 & $9.38 \times 10^{-2}$ & $6.04 \times 10^{-4}$ \\
\hline 5 & 25 & 60 & Melamine & 33.5 & 0.5 -fold & 5 & 45 & 25 & $9.38 \times 10^{-3}$ & $6.07 \times 10^{-4}$ \\
\hline 6 & 60 & 25 & Glass & 67 & 0.5 -fold & 10 & 45 & 80 & $1.88 \times 10^{-2}$ & n.d. \\
\hline 7 & 60 & 60 & Melamine & 6.7 & 0.5 -fold & 10 & 30 & 4 & $1.88 \times 10^{-3}$ & $1.22 \times 10^{-3}$ \\
\hline 8 & 25 & 25 & Melamine & 6.7 & 1-fold & 20 & 45 & 80 & $3.75 \times 10^{-3}$ & $1.21 \times 10^{-3}$ \\
\hline 9 & 60 & 25 & Porcelain & 6.7 & 1 -fold & 5 & 30 & 25 & $3.75 \times 10^{-3}$ & $1.19 \times 10^{-3}$ \\
\hline 10 & 60 & 25 & Melamine & 33.5 & 5 -fold & 20 & 15 & 4 & $9.38 \times 10^{-2}$ & $6.02 \times 10^{-4}$ \\
\hline 11 & 60 & 60 & Melamine & 67 & 1 -fold & 10 & 15 & 25 & $3.75 \times 10^{-2}$ & n.d. \\
\hline 12 & 60 & 60 & Glass & 6.7 & 5 -fold & 5 & 45 & 4 & $1.88 \times 10^{-2}$ & $1.19 \times 10^{-3}$ \\
\hline 13 & 60 & 60 & Porcelain & 33.5 & 0.5 -fold & 20 & 30 & 80 & $9.38 \times 10^{-3}$ & $6.01 \times 10^{-4}$ \\
\hline 14 & 60 & 60 & Porcelain & 67 & 5-fold & 20 & 45 & 25 & $1.88 \times 10^{-1}$ & n.d. \\
\hline 15 & 25 & 60 & Porcelain & 33.5 & 1-fold & 10 & 45 & 4 & $1.88 \times 10^{-2}$ & $7.08 \times 10^{-4}$ \\
\hline 16 & 25 & 60 & Glass & 6.7 & 0.5 -fold & 20 & 15 & 25 & $1.88 \times 10^{-3}$ & $1.23 \times 10^{-3}$ \\
\hline 17 & 25 & 60 & Melamine & 67 & 5-fold & 5 & 30 & 80 & $1.88 \times 10^{-1}$ & n.d. \\
\hline 18 & 25 & 60 & Glass & 67 & 1 -fold & 20 & 30 & 4 & $3.75 \times 10^{-2}$ & n.d. \\
\hline
\end{tabular}

Note 1 : for trial 1 , the concentration of triclosan in deionized water was calculated as followed: $6.7 \mathrm{~g} \mathrm{l}^{-1} \times 0.056 \%($ triclosan $/$ detergent, $\mathrm{g} / \mathrm{g}) \times 5=1.88 \times 10^{-2} \mathrm{~g} \mathrm{l}^{-1}$.

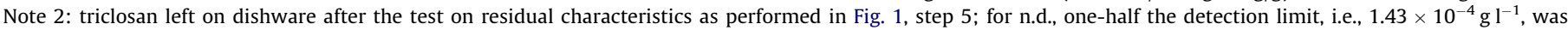
assigned for the analysis by the Taguchi method.

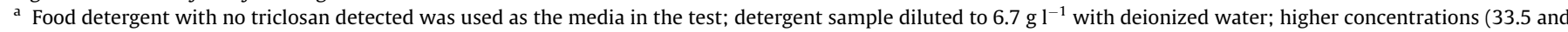
$67 \mathrm{~g} \mathrm{l}^{-1}$ ) were also prepared for the test.

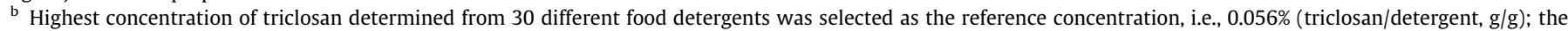
triclosan was spiked after the detergent media (with no triclosan detected as mentioned above) was first diluted.

Table 2

$\mathrm{L}_{9}\left(3^{4}\right)$ orthogonal array for residual characteristics determinations on fruits

\begin{tabular}{|c|c|c|c|c|c|c|}
\hline Trial & Fruits & $\begin{array}{l}\text { Detergent conc. } \\
\left(\mathrm{g} \mathrm{l}^{-1}\right)\end{array}$ & $\begin{array}{l}\text { Triclosan } \\
\text { conc. }^{\text {b }}\end{array}$ & $\begin{array}{l}\text { Immersion time } \\
(\mathrm{min})\end{array}$ & $\begin{array}{l}\text { Note 1: Triclosan in deionized water before } \\
\text { the test }\left(\mathrm{g} \mathrm{l}^{-1}\right)\end{array}$ & $\begin{array}{l}\text { Note 2: Triclosan left on fruit (mg } \\
\text { triclosan/g fruit) }\end{array}$ \\
\hline 1 & Tomato & 6.7 & 5-fold & 10 & $1.88 \times 10^{-2}$ & $2.10 \times 10^{-4}$ \\
\hline 2 & Grape & 67 & 0.5 -fold & 10 & $1.88 \times 10^{-2}$ & $3.63 \times 10^{-5}$ \\
\hline 3 & Apple & 67 & 5-fold & 20 & $1.88 \times 10^{-1}$ & $3.75 \times 10^{-4}$ \\
\hline 4 & Apple & 33.5 & 1 -fold & 10 & $1.88 \times 10^{-2}$ & $5.73 \times 10^{-5}$ \\
\hline 5 & Tomato & 33.5 & 0.5 -fold & 20 & $9.38 \times 10^{-3}$ & $3.63 \times 10^{-5}$ \\
\hline 6 & Tomato & 67 & 1-fold & 5 & $3.75 \times 10^{-2}$ & $3.63 \times 10^{-5}$ \\
\hline 7 & Grape & 33.5 & 5-fold & 5 & $9.38 \times 10^{-2}$ & $6.51 \times 10^{-4}$ \\
\hline 8 & Apple & 6.7 & 0.5 -fold & 5 & $1.88 \times 10^{-3}$ & $3.63 \times 10^{-5}$ \\
\hline 9 & Grape & 6.7 & 1-fold & 20 & $3.75 \times 10^{-3}$ & $2.01 \times 10^{-4}$ \\
\hline
\end{tabular}

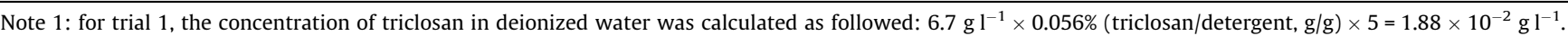
Note 2: triclosan left on fruit after the test on residual characteristics as performed in Fig. 2, step 4.

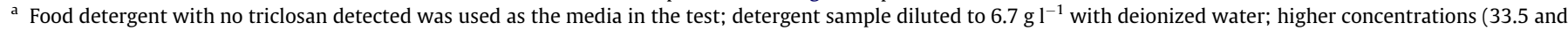
$67 \mathrm{~g} \mathrm{l}^{-1}$ ) were also prepared for the test.

${ }^{b}$ Highest concentration of triclosan determined from 30 different food detergents was selected as the reference concentration, i.e., $0.056 \%$ (triclosan/detergent, g/g) ; the triclosan was spiked after the detergent media (with no triclosan detected as mentioned above) was first diluted. 


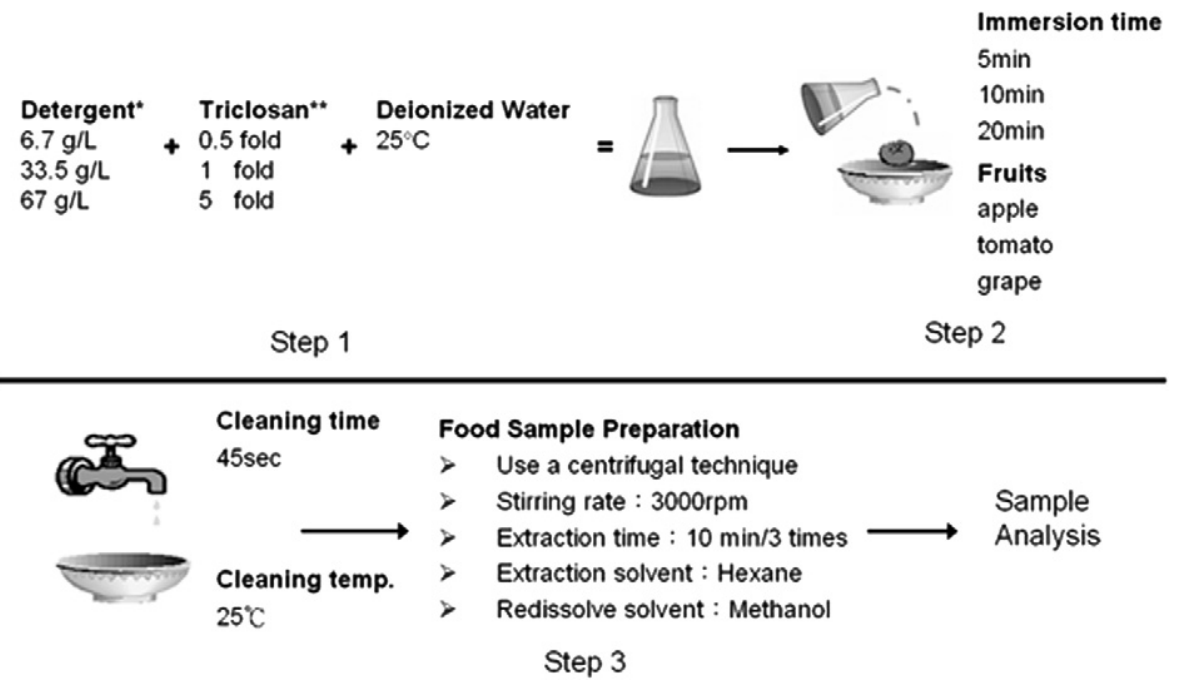

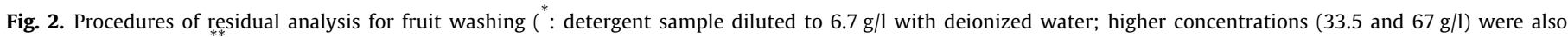

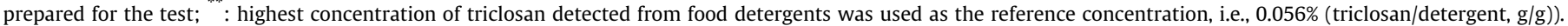

was re-dissolved in $5 \mathrm{ml}$ methanol and transferred to a sample vial for further analysis.

Design Expert 7.0 (Stat-Ease, Minneapolis, MN, USA) (Montgomery, 2001; Alben, 2002) was used to model the process and predict optimum conditions to minimize the residue of food detergents either on dishware or fruits.

\subsection{Instrumentation}

A Perkin-Elmer Series 200 LC with Model 785A UV/vis detector was used for the analysis. The chromatographic separations were performed on a SUPELCO 516 C18 column (Bellefonte, PA, USA) using a mobile phase consisting of acetonitrile-water 70:30 (v/v) at a flow rate of $1 \mathrm{ml} \mathrm{min}{ }^{-1}$ while UV detection at $280 \mathrm{~nm}$ was selected (George et al., 1980). By comparisons of the retention time and the UV spectra of standards, triclosan in samples were identified.

The identity of triclosan was also confirmed by gas chromatography. A Perkin-Elmer Autosystem XL Chromatograph equipped with a fused silica capillary column DB-5 $(30 \mathrm{~m} \times 0.25 \mathrm{~mm}$ ID $\times 1 \mathrm{~m}$ film thickness) (J\&W Scientific, CA, USA) and a Perkin-Elmer Turbo Mass, mass spectrometer were employed. The GC/MS analytical conditions reported elsewhere were followed in this study (Sanches-Silva et al., 2005).

\section{Results and discussion}

\subsection{Determination of triclosan}

Standard solutions of triclosan in methanol ranged from 1 to $180 \mathrm{mg} \mathrm{l}^{-1}$ were prepared in this study. The calibration line established was $Y=(910.2 \pm 8.0) X+(-593.6 \pm 632.1)$ with $R^{2}=0.997$, where $Y$ and $X$ equaled peak area and concentration of triclosan, respectively. To determine the precision and accuracy of the analytical method, spiked triclosan samples $\left(30 \mathrm{mg} \mathrm{l}^{-1}\right)$ of detergents were analyzed seven times. The relative standard deviations were found to be less than $6 \%$, and the recoveries were $100 \pm 4 \%$. Another spiked samples $\left(1 \mathrm{mg} \mathrm{l}^{-1}\right.$ ) were also analyzed seven times to determine the detection limits, and the MDLs were found to be $0.285 \mathrm{mg} \mathrm{l}^{-1}$.

\subsection{Distribution of triclosan in detergent samples}

Table 3 summarized the concentrations of triclosan in food detergent samples of Taiwan. The concentrations detected ranged from $1.7 \times 10^{-2}$ to $5.6 \times 10^{-1}$ (triclosan/detergent, $\mathrm{mg} \mathrm{g}^{-1}$ ).

As mentioned above, $43 \%$ of the antibacterial agents added in food detergents of Taiwan were labeled to contain triclosan (Tsai,

Table 3

Concentrations of triclosan detected in household food detergents of Taiwan

\begin{tabular}{|c|c|c|c|c|c|}
\hline Detergent & $\begin{array}{l}\text { Antibacterial } \\
\text { agent }^{\mathrm{a}}\end{array}$ & $\begin{array}{l}\text { Conc. of triclosan detected \% (triclosan g/ } \\
\text { detergent g) }\end{array}$ & Detergent & $\begin{array}{l}\text { Antibacterial } \\
\text { agent }^{\mathrm{a}}\end{array}$ & $\begin{array}{l}\text { Conc. of triclosan detected \% (triclosan g/ } \\
\text { detergent g) }\end{array}$ \\
\hline 1 & Not specified & n.d. & 16 & Triclosan & 0.017 \\
\hline 2 & Triclosan & 0.036 & 17 & Tea tree oil & 0.022 \\
\hline 3 & Triclosan & 0.033 & 18 & Aloe & 0.023 \\
\hline 4 & Triclosan & 0.54 & 19 & Triclosan & 0.12 \\
\hline 5 & Not specified & n.d. & 20 & Aloe & 0.021 \\
\hline 6 & Tea tree oil & 0.019 & 21 & Not specified & 0.56 \\
\hline 7 & Araceae $^{\mathrm{b}}$ & 0.019 & 22 & Triclosan & 0.073 \\
\hline 8 & Not specified & 0.017 & 23 & Triclosan & 0.019 \\
\hline 9 & Triclosan & 0.063 & 24 & Tea tree oil & 0.018 \\
\hline 10 & Others & 0.039 & 25 & Tea tree oil & 0.019 \\
\hline 11 & Triclosan & 0.098 & 26 & Tea tree oil & 0.019 \\
\hline 12 & Triclosan & 0.13 & 27 & Not specified & 0.017 \\
\hline 13 & Not specified & n.d. & 28 & Triclosan & 0.017 \\
\hline 14 & Not specified & 0.018 & 29 & Triclosan & 0.42 \\
\hline 15 & Triclosan & 0.028 & 30 & Aloe & 0.024 \\
\hline
\end{tabular}

a Antibacterial agent listed on the label of the product.

b Acorus gramineus. 


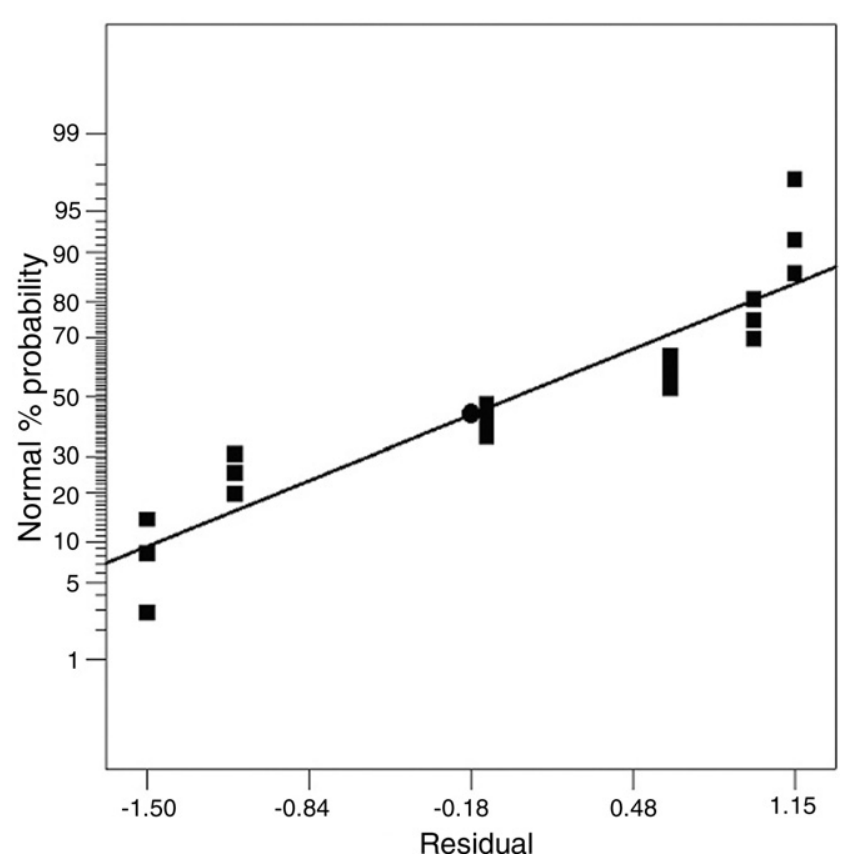

Fig. 3. Normal probability plot of the residuals for dishware analysis. The $x$-axis, statistical residual, means the difference between the observed value and the value predicted by the model.

2005). However, as shown in Table 3, 90\% (27/30) of the samples were found to contain triclosan even when the label showed no triclosan containing.

\subsection{Residual characteristics of triclosan}

Fractional factorial design approaches were applied to study the main factors that might affect the residual characteristics when using detergents (Montgomery, 2001). As shown in Tables 1 and 2 , factors that might affect the residue of triclosan from food detergents on dishware as well as on fruits were investigated, respectively.

To determine the residual characteristics of triclosan on dishware from food detergents, ANOVA test including all factors was performed first which showed the model was significant $(p<0.0001)$ and the main contributing factor was the concentrations of detergents $(p<0.0001)$. However, the normal probability plot of residuals showed the model did not have acceptable adequacy (Fig. 3). Backward elimination procedure was then performed by the Design-Expert 7.0 and only the dish materials and the concentrations of detergents were kept in the model. Further residual analysis showed the normality was improved obviously (Fig. 4). The results suggested that the triclosan left on the dishware will increase as the concentrations of detergents used increased. On the other hand, different dish materials might also have different tendencies of having triclosan left on them $(p=0.0384)$. For example, it was suggested from the results that the triclosan left on dish material made of glass might be less when compared with the material made of porcelain. Except the two factors mentioned above, all other factors tested were independent of having the triclosan left on the dishware.

To determine the residual characteristics of triclosan on fruits from food detergents, ANOVA test on factors including the concentration of triclosan spiked in food detergent, varieties of fruits, concentration of surfactant, and time spent for the detergent soaking process on fruits were also performed. Backward elimination procedure was used by the Design-Expert 7.0 and only the concentra-

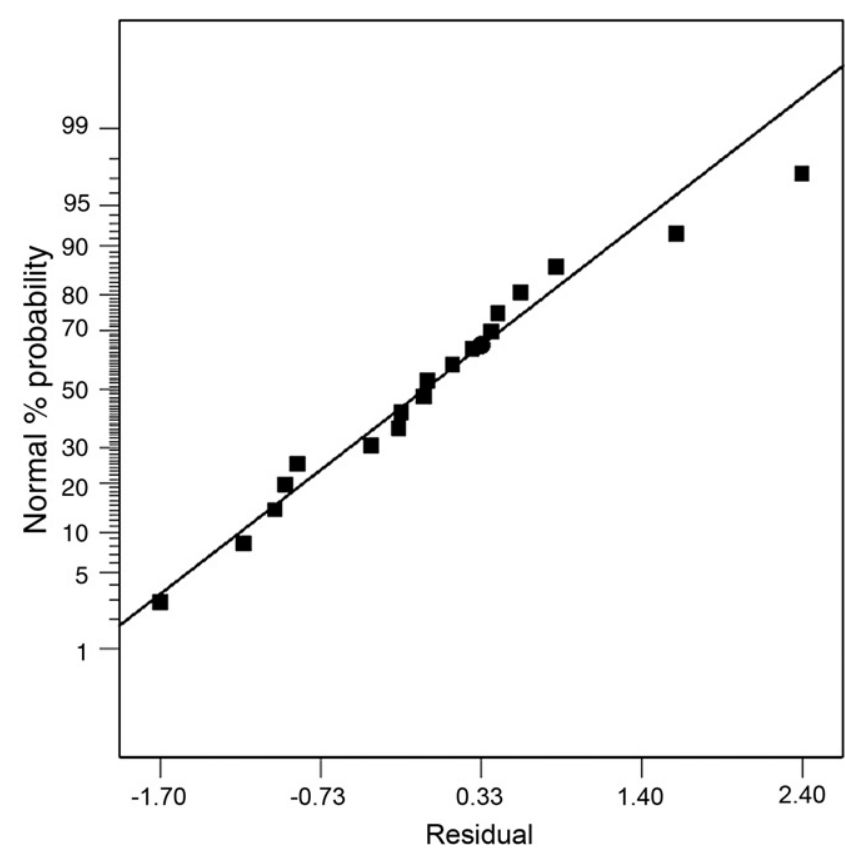

Fig. 4. Normal probability plot of the residual for dishware analysis after backward elimination procedure. The $x$-axis, statistical residual, means the difference between the observed value and the value predicted by the model.

tion of triclosan spiked in food detergent was kept in the model ( $p=0.033$ ). However, the normal probability of residuals showed the model did not have acceptable adequacy and a transformation was suggested. Data transformations by the Design-Expert including square root, natural $\log$, base $10 \mathrm{log}$, and inverse sqrt were then performed following by the backward elimination procedure. Acceptable normality of residual analysis appeared when only the concentration of triclosan spiked and the varieties of fruits were kept in the model ( $p=0.0203$ ) under square root transformation. The results suggested that the residue of triclosan on fruits will increase as the concentrations of triclosan spiked increased. On the other hand, different fruits did not seem to have different tendencies of having triclosan left on them $(p=0.125)$.

\subsection{Maximum estimated dose of triclosan exposures from the use of household food detergents}

Maximum dose of daily triclosan exposures from the use of household food detergents in Taiwan was estimated in this study. The highest concentrations of triclosan found from the tests on residual characteristics were adopted for the worst-case calculations, and two possible sources of exposures were considered including daily water consumption and fruits intakes. The daily water intake rate was assumed to be $2000 \mathrm{ml} /$ day for adult with average body weight of $70 \mathrm{~kg}$ (Hallenbeck, 1993), while the average fruits intake rates in Taiwan were assumed to be 172.12 $\mathrm{g} /$ day and $208.28 \mathrm{~g}$ /day for male and female, respectively (Tzeng et al., 1999). The maximum dose of triclosan exposures from water consumption was then estimated to be $0.035 \mathrm{mg} / \mathrm{day} \mathrm{kg}$. On the other hand, the maximum intakes of triclosan from fruits were estimated to be 1.60 and $1.93 \mathrm{~g} / \mathrm{day} \mathrm{kg}$ for male and female in Taiwan, respectively.

The exposure assessment of triclosan for infant through breast milk feeding has been reported elsewhere, while the maximum dose calculated was around $7.4 \mathrm{~g}$ /day kg (Dayan, 2007). Based on animal study, the oral no observed adverse effect level (NOAEL) for triclosan exposure was also established as $50 \mathrm{mg} /$ day $\mathrm{kg}$ for pups (Dayan, 2007). As mentioned above, the maximum dose of 
triclosan exposure from both water consumption and fruit intakes in this study was around $0.037 \mathrm{mg} /$ day $\mathrm{kg} \quad(0.035 \mathrm{mg} /$ day $\mathrm{kg}+1.93 \mathrm{~g} / \mathrm{day} \mathrm{kg}$ ). The margin of exposure (MOE) can then be calculated as $50 / 0.037=1351$. As for the safety factor, current convention would be to use a 500 or better a 1000 -fold factor (Dayan, 2007). Whatever safety factor is employed, the maximum dose of triclosan exposure estimated in this study is less than the NOAEL. Therefore there is no evidence to suggest that the presence of triclosan after detergent using in this study will present a health risk.

Besides detergents, toothpaste is considered to be another important human source of exposure to triclosan. For example, an estimated $20-25 \%$ of all toothpastes sold in Sweden were reported to contain triclosan, and around tons were used per year (Edwardsson et al., 2005). However, no data is currently available in Taiwan regarding the amounts of triclosan contained in toothpaste. Therefore a comprehensive evaluation is suggested to assess the possible health effects that might be caused due to the exposures of triclosan from different sources.

\section{Conclusions}

The results of the study demonstrated that triclosan were widely added in food detergents as the antibacterial agents in Taiwan. Possible formation of chloroform in household due to the reaction with chlorinated water should therefore be concerned. To assess the associate risks, the concentrations of triclosan in wastewater as well as their environmental fates needed to be determined in Taiwan since it can be expected that triclosan will not only be found in household but will also be detected in the following aquatic environments.

As for the residual characteristics, it was found that the concentrations of detergents used as well as the materials of dishware will affect the amount of triclosan left on dishware. On the other hand, only the concentration of triclosan in detergents might contribute to the triclosan left on fruits. It is suggested that proper instructions should be put on the labels of the products to avoid possible exposures from overuse of detergents.

\section{Acknowledgement}

This study was supported by grant from the Department of Health, Executive Yuan, Taiwan (DOH94-TD-F-113-019).

\section{References}

Adolfsson-Erici, M., Pettersson, M., Parkkonen, J., Sturve, J., 2002. Triclosan, a commonly used bactericide found in human milk and in the aquatic environment in Sweden. Chemosphere 46, 1485-1489.

Alben, K.T., 2002. Design, analyze, and optimize with Design-Expert. Anal. Chem. 74 222A-223A.
Canosa, P., Morales, S., Rodriguez, I., Rubi, E., Cela, R., Gomez, M., 2005. Aquatic degradation of triclosan and formation of toxic chlorophenols in presence of low concentration of free chlorine. Anal. Bioanal. Chem. 383, 1119-1126.

Ciba Specialty Chemical, 1998. Fact Sheet - PEC Calculation of Triclosan. Basle, Switzerland.

CNS standards 3800, 2000. Synthetic detergent for food and kitchen utensil, Bureau of Standards, Metrology and Inspection, MOEA, Taiwan, <http://www. cnsonline.com.tw/en/preview/preview.jsp?general_no=0380000\&language $=C \&$ pagecount $=7>$.

Dayan, A.D., 2007. Risk assessment of triclosan [Irgasa] in human breast milk. Food Chem. Toxicol. 45, 125-129.

Di Corcia, A., 1998. Characterization of surfactants and their biointermediates by liquid chromatography-mass spectrometry. J. Chromatogr. A 794, 165-185.

Edwardsson, L.B., Adolfsson-Erici, M., Backman, N., 2005. Risks and benefits with triclosan containing toothpastes. Tandlakartidningen 97, 58-64.

Fiss, E.M., Rule, K.L., Vikesland, P.J., 2007. Formation of chloroform and other chlorinated byproducts by chlorination of triclosan-containing antibacterial products. Environ. Sci. Technol. 41, 2387-2394.

George, E.D., Hillier, E.J., Krishnan, S., 1980. Analysis of trichlorocarbanilide and triclosanin soaps by reverse phase high pressure liquid chromatography. J. Am. Oil Chem. Soc. 57, 131-134.

Halden, R.U., Paull, D.H., 2005. Co-occurrence of triclocarban and triclosan in US water resources. Environ. Sci. Technol. 39, 1420-1426.

Hallenbeck, W.H., 1993. Quantitative Risk Assessment for Environmental and Occupational Health, second ed. Lewis Publishers, New York.

Hicks, C.R., 1999. Fundamental Concepts in the Design of Experiments. Oxford University Press, New York.

Kanetoshi, A., Ogawa, H., Katsura, E., Kaneshima, H., 1987. Chlorination of Irgasan DP300 and formation of dioxins from its chlorinated derivatives. J. Chromatogr. 389, 139-153.

Kanetoshi, A., Ogawa, H., Katsura, E., Kaneshima, H., Miura, T., 1988. Formation of polychlorinated dibenzo-p-dioxin from 2,4,4'-trichloro-2'-hydroxydiphenyl ether and its chlorinated derivatives by exposure to sunlight. J. Chromatogr. 454, 145-155.

Latch, D.E., Packer, J.L., Arnold, W.A., McNeill, K.J., 2003. Photochemical conversion of triclosan to 2,8-dichlorodibenzo-p-dioxin in aqueous solution. Photochem. Photobiol. A. Chem. 158, 63-66.

Levy, S.B., 2001. Antibacterial household products: cause for concern. Emerg. Infect. Dis. 7 (Suppl.), 512-515.

Lindström, A., Buerge, IJ., Poiger, T, Bergqvist, P.A, Müller, M.D., Buser, H.R., 2002 Occurrence and environmental behavior of the bactericide triclosan and its methyl derivative in surface waters and in wastewater. Environ. Sci. Technol. 36, 2322-2329.

McMurry, L.M., Oethinger, M., Levy, S.B., 1998. Triclosan targets lipid synthesis. Nature 94, 531-532.

Montgomery, D.C., 2001. Design and Analysis of Experiments, fifth ed. Wiley, New York.

Rule, K.L., Ebbett, V.R., Vikesland, P.J., 2005. Formation of chloroform and chlorinated organics by free-chlorine-mediated oxidation of triclosan. Environ. Sci. Technol. 39, 3176-3185.

Sanches-Silva, A., Sendón-García, R., López-Hernández, J., Paseiro-Losada, P., 2005. Determination of triclosan in foodstuffs. J. Sep. Sci. 28, 65-72.

Singer, H.P., Muller, S.R., Tixier, C., Pillonel, L., 2002. Triclosan: occurrence and fate of a widely used biocide in the aquatic environment: field measurements in wastewater treatment plants, surface waters, and lake sediments. Environ. Sci. Technol. 36, 4998-5004.

Tsai, S.W., 2005. The Disinfectants for Food: Usage Investigation and Residual Analysis. DOH94-TD-F-113-019. Department of Health, Executive Yuan, Taiwan.

Tzeng, M.S., Kao, M.D., Yeh, W.T., Pan, W.H., 1999. Food consumption frequency and eating habit among Taiwanese-NAHSIT 1993-1996. Nutr. Sci. J. 24, 59-80. Taiwan.

US Code of Federal Regulations, Title 40, Part 136, Appendix B, Definition and procedure for the determination of the method detection limit, revision 1.11 .

Ying, G.G., 2006. Fate, behavior and effects of surfactants and their degradation products in the environment. Environ. Int. 32, 417-431. 